\title{
The Muwashahat in the Studies of Recent Researchers: A Prosody Study
}

Sahar Muhammad Mawloud Shafiq Al-Rawi*, Amer Mahidi Saleh Al-Alwani

Department of Arabic Language, College of Education for Human Sciences, University of Anbar, Iraq

* $\underline{\text { Ib97mark@gmail.com }}$

\begin{abstract}
:
This study deals with the emerging arts of poetry, and the extent of their deviation from Khalili poetry, for Arab poetry has remained for ages controlled by the balance of the known poem since the preIslamic era. The syntactic aspects of this balance are based by Al-Khalil. However, with the development of Arab civilization and its mixing with other civilizations, attempts to depart from AlKhalili system in its various forms began. The most prominent of these deviations are the seven poetic arts: Al-Muwashahat, Al-Dobbit, Al-Zajal, Al- Aquma, Al- Mawalia, Al-Band and Al-Kan Wa Kan, which are the beginning of a stepping stone to poetic renewal in the modern era.
\end{abstract}

Keywords: $\quad$ Muwashah; Poetry; Civilization; Modern; Renewal.

Crossref doi https://doi.org/10.51345/.v32i1.265.g189 


\section{الموشحات في دراسات المحدَثين: دراسة عروضية \\ سحر محمد مولود شفيق الراوي"، عامر مهيدي صالح العلواني

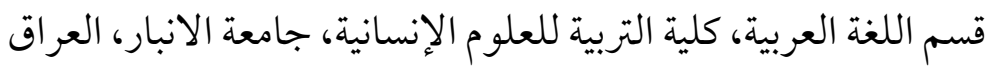 \\ * Ib97mark@gmail.com}

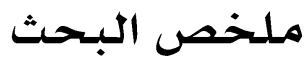

تتناول هذه الدراسة فنون الشعر المستحدثة، ومدى خروجها عن الشعر الخليلي، فالشعر العربي ظل على مدى عصور مضبوطًا

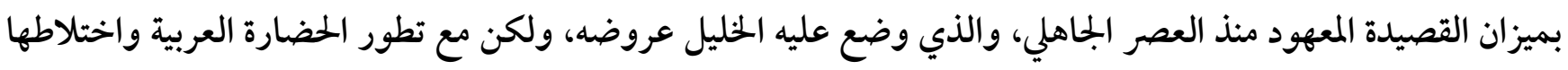

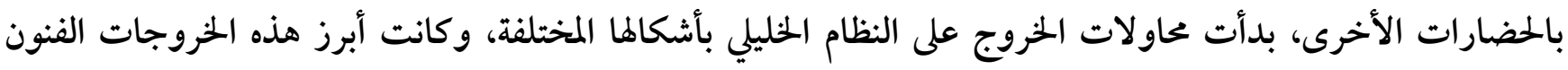

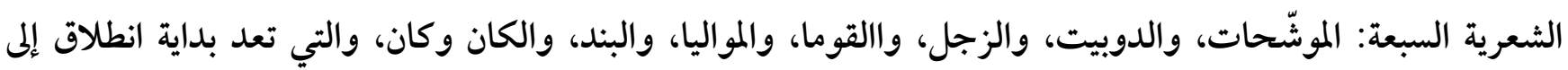

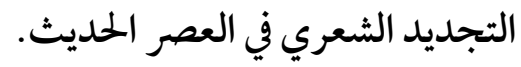


المقدمة:

الحمد لله رب العالمين، والصلاة والسلام على سيد المرسلين وإمام المتقين، سيدنا محمد وعلى آله الطيبين الطاهرين وأصحابه الغُّر الميامين، وبعد: فإن الشعر تعبير صادق عن البيئة والحضارة التي نبخ منها، فتأثير الشعر في عو اطف الجماهير ووجدانهم، نابع من تصويره لحياتهم وبيئتهم، ومعالجته لما يعيشونهم في يومياتهم، لذلك كان حتًّا على الشعراء أن يسعوا إلى يل ئ التجديد في الشعر ليو اكبوا البيئة التي يعيشون فيها؛ "وقد فرض تطور الحياة العربية نوعًا من التطور والتجديد على أوزان الشعر العربي وأشكاله، وكان هذا التطور استجابة للتطور الخضاري للمجتمع العربي، وتلبية لتطلع المبدعين إلى التعبير عَّما يجول في أذهانهم بطرائق جديدة، ولاسيا بعدما اتسعت مساحة الدولة العربية، وتنوعت بيئتها؛ وتعددت أجناس البشر في مجتمعها، وامتزجت ثثافات كثيرة في حضارة واحدة هي الحضارة العربية الإسلامية. وقد لامس هذا التجديد الشكل والوزن، ولما كان هذا الجديد خارجاً عن مألوف ما جاء عن العرب في الإبداع المنظوم الموزون، أوجدوا له مسمياتٍ جديدة تدل عليه وتحافظ على ما اتفت عليه مما كان سائداً من أوزان الشعر وأشكاله المعروفة التي ظلت بضو ابطها حتى اليوم"(1).

\section{أهـداف البحث :}

يهدف هذا النوع من الدراسة إلى وضع رؤية واضحة حول هذا الفن المستحدث، من خلال دراسات الباحثين المحدثين، ومناقشة هذه الآراء واستخلاص الآراء الصائبة أو الأقرب إلى الصواب من خلال هذه المناقشات.

\section{المطلب الأول : تعريف الموشّحات} الموشّحات هو أحد فنون الشعر العربي السبعة، وعرفها الابشيهي في المستطرف: (الشعر القريض، والموشّح، والدوبيت، والزجل، والمو اليا، و الكان و كان ، والقوما)(2). 
نلاحظ من خلال الرجوع الى المعاجم أن أول استعمال له في تسميته له خطتان (الوشاح)، ويياري هذا الاستخدام في القدم مؤنث الكلمة: موشحة، فهي تطلق على الظباء والشاة والطير: التي لها طرتان من جانبيها (3) اشتقت كلمة الموشّح، من لفظة الوشاح، ومعناها (حلي النساء)، جاء في "لسان العرب" مادة "وَشَحَح":

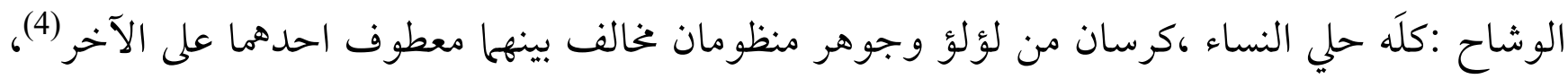

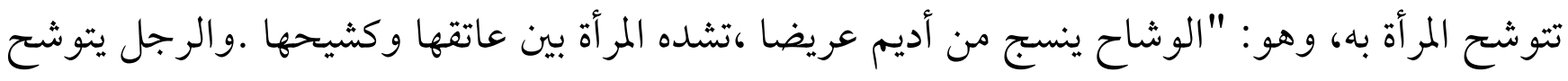

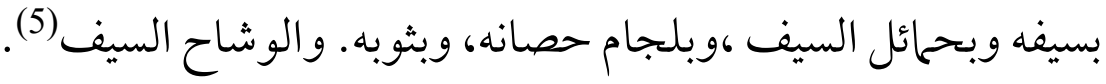
اصطلاحًا: عرفها ابن سناء الملك الأندلسي بأنها "كلام منظوم على وزن خصوص، وهو يتألف في الأكثر من

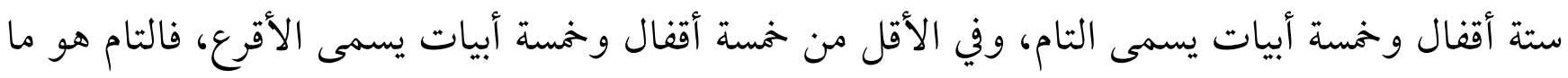

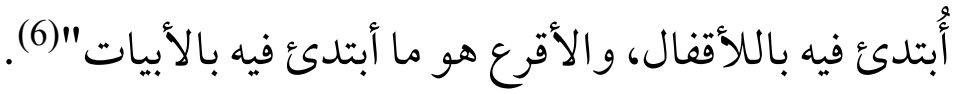
وعرفها أنطو ان محسن: هي القصيدة أو القطعة الشعرية الموضوعة للغناء، تتنوع أوزانه وقوافيه؛ وهذا التنوع بئات يجعلها أقرب الى قطعة موسيقية منه إلى قصيدة شعرية (7). وفي الأدب فن شعري نشأ في أوساط الشعب الأندلسي خلال القرن الثالث الهجري؛ لإرضاء حاجة الشعب. وعروضيًّ يتميز بتعدد القوافي وبخروجه على بحور الشعر المعروفة في بعض الأحيان وتنويعها في الموشّح الو احد، وبتقسيمه الى أجزاء لا نجدها في ألو ان النظم الاخرى مع استعاله اللهجة العامية أو الاعجمية في

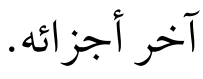
وهذا ما لا أستسيغه أنا كباحثة يُحِبَّة للكلمة الفصيحة الصحيحة. وقد اختلف المؤرخون في تسميته أول وشّاح أندلسي، فقال بعضهم: إنّه محمد بن محمود القبري، وقال آخرون:

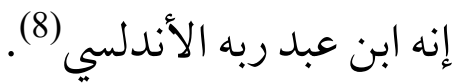
أما أجزاء الموشّح فهي أجزاء يكون بجموعها الموشّح الكامل وهي: المطلع، القفل، الدور، السمط، الغصن، البيت، الخرجة (9). 
فالموشّحات بشكل عام قسمين: منها ما جاء على أوزان أشعار العرب، وهذا الذي أحببته لنفسي، ومنها ما لا وزن له؛ كما يقول ابن سناء الملك (10). وسأتناول توضيحها مع ذكر الأمثلة

\section{المطلب الثاني: العروض والقافية يِّ الموشّحات}

يعد الموشّح خروجًا على نظام القصيدة القديم المعروف عند العرب، إذ يقوم على تعدد الأوزان والقوافي، على غير المعهود في الشعر العمودي؛ فالموشّح يتميز بتعداد أوزانهِ وتنوّع قوافيهِ تبعًا لرغبة قائلهِ وقدرتهِ على التصرّف في أفانين الكلام (11).

$$
\text { يتكون الموشّح من عدة أجزاء الموشّح: هي: }
$$

1 - مطلع القصيدة، ويسمى ((المطلع، أو المذهب)"، ويتكون عادة من شطر أو شطرين أو أربعة أشطر، وقد تختلف قافية الغصنين، وقد تتفق، وقد يخلو الموشّح من (المطلع)" فيسمى حينثِذ (الأقرع))، أما الموشّح الذي

$$
\text { فمن أمثلة الموشّح التامع فيسمى ((التام)|(12): }
$$

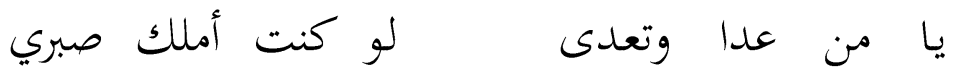

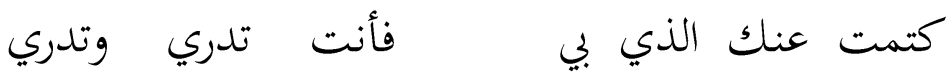

هيهات كتم الغرام

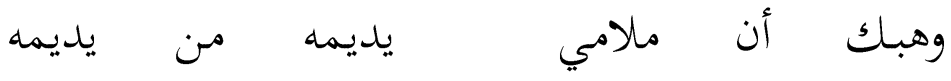

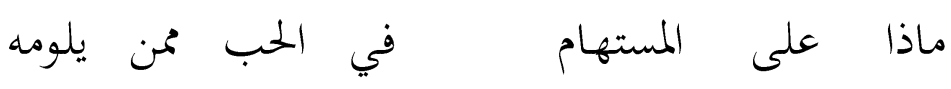

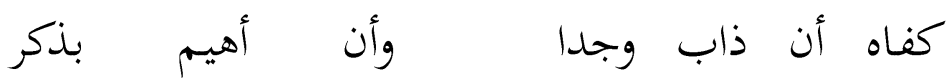

فني الهوى والشحوب للصب أوضح عذر

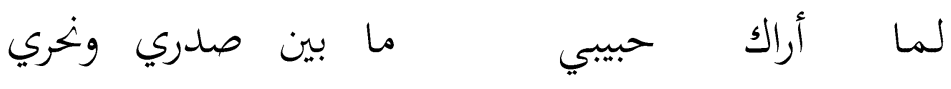


فقد بدأ ابن الخباز موشحه بمطلع عبارة عن بيتين تتفق قافيتها مع قافية الأقفال وهي قافية الراء المكسورة. ومن أمثلة الموشّح الأقرع قول الجزار (13):

أما والهوى أنني مُدْنفتُ

بحب رشا قلّما ينصف

أطاوعه وهو لي مخلف

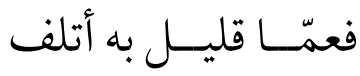

فلم يبدأ الجزار بمطلع أو دخل في الدور الأول مباشرة.

2- الدور: وهو بجموعة الأبيات التي تلي المطلح، وإن كان الموشّح أقرع فإن الدور يقع في مستهل الموشّح، ويتكون الدور من بجموعة من الأقسمة لا تقل عن ثلاثة، ولا مانع من أن تزيد عن ثلاثة بشرط أن تتكرر بنفس العدد في بقية الموشّح، وأن تكون من وزن المطلع، ولكن بقافية مختلفة عن قافيته، وتلتزم في أشطر الدور الو احد.

3 - السمط: هو كل شطر من أشطر الدور، وقد يتكون السمط من فقرة واحدة - كما في موشح الجزار -، أو من فقرتين -كما في موشح ابن الخباز. 4- القفل أو المركز: وهو ما يلي الدور مباشرة، وهو شبيه بالمطلع في الموشّح التام من جميع النواحي؛ أي أنه شبيهه في القوافي، وعدد الأغصان، وليست الموشّحة مشروطة بعدد ثابت من الأقفال. 5 - البيت: ويتكون البيت في الموشّح من الدور مضافًا إليه القفل الذي يليه. 6- الغصن: هو كل شطر من أشطر المطلع أو القفل أو الخرجة، وتتساوى الأغصان عددًا وترتيبًا وقافيةً في كل الموشّحة، وقلّما يشذ الوشاح عن هذه القاعدة، وأقل عدد للأغصان في مطلع أية موشحة ـ ويالتالي في الأقفال والخرجة ـ اثنان، وييجوز أن تتفق قافية الغصنين ويجوز أن تختلف، على أنه من المألوف أن تتكون أقفال الموشّحة من أربعة أغصان. 
7 - الخرجة: وهي آخر قفل في الموشّحة، وهي كالقفل في كل شروطه، غير أنها تقع في آخر الموشّحة وهي مع

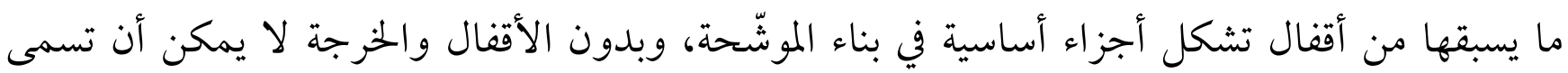
المنظومة موشحًا.

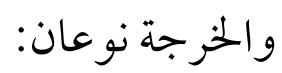
أ. خرجة معربة؛ وهي التي تكون فصيحة اللفظ بعيدة عن العامية، كما في الموشّحتين السابقتين.

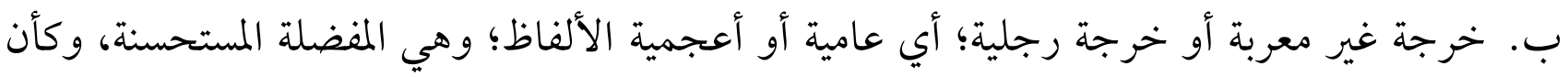
القصد منها هو الإشعار بختام الموشّح (14). فمن أمثلة الخرجات غير المعربة(15):

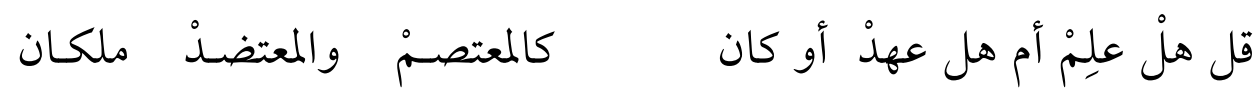
فقد وقف بالسكون على: (علم، وعهل، وكالمتتصم، والمتتضد). ومن أمثلة الخرجة العامية خرجة موشح ابن حاتمة الأنصاري (16): صبي عشقت روحي وش نحفظ اللسـان عـــاشتق بترجمــــــان

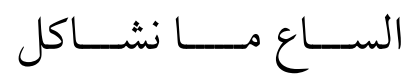
ومن الخرجة العجمية قول الأعمى التطليلي (17):

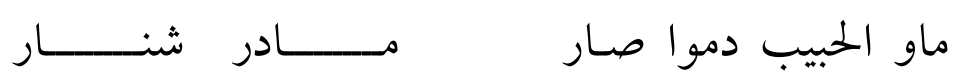
بنفيس رامش كف دموعاز

وباستخدام الموشّحين للخرجة غير المعربة ربطوا به بين الزجل والموشّح، يقول ابن حجة الحموي: (الفرق بين

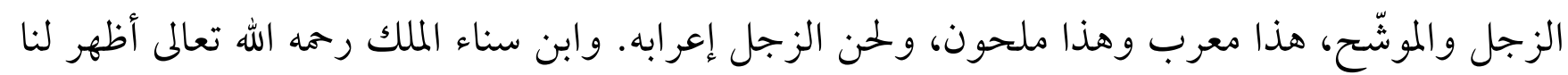

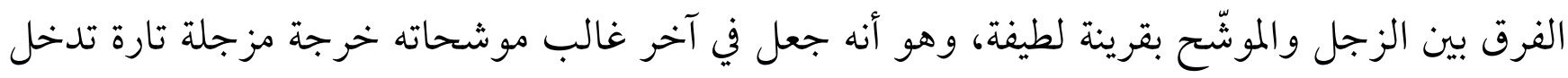

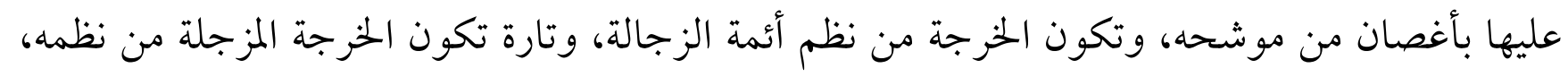
وغالب أئمة الوشاحة فعلوا ذلك، ليظهر الفرق، وهو مثل الصبح ظاهر ||(18). 
والموشّح يعتمد بالدرجة الأساس في هيكلهِ وبنائهِ على الخرجة بخلاف القصيدة العموديَّة التي تعتمدُ على

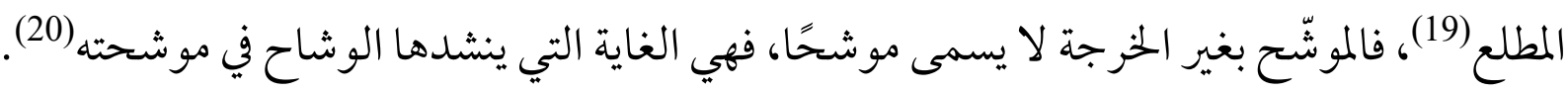

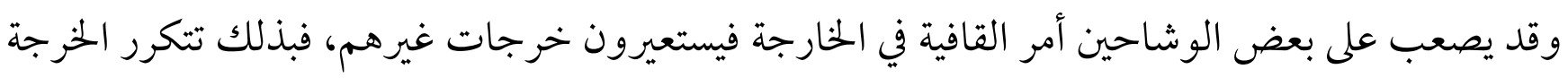

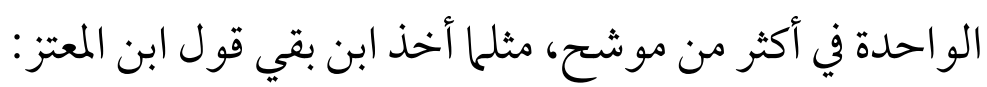

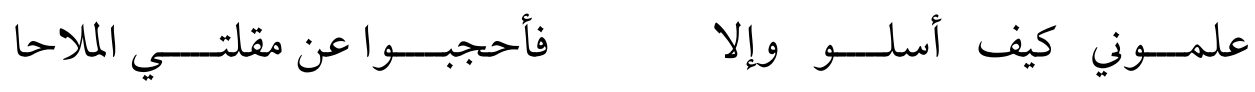
فجعله خرجة لموشح

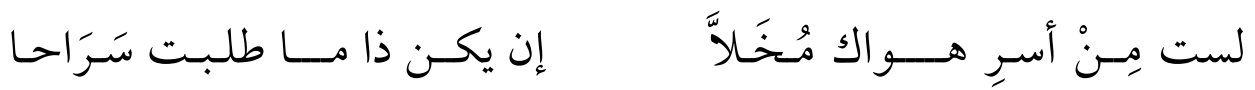

قد تلزمت هــــو اك ضمانـا

أعطني من مقلتيك الأمانا

فلقد كابدت فيك زمانـا

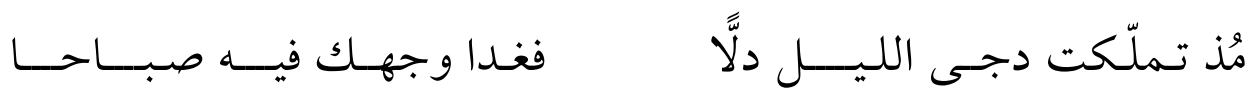

لست أشكو غير هجر مو اصـل

مذ منعتُ القلب عن عذل عـاذل

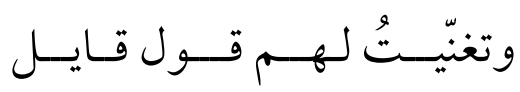

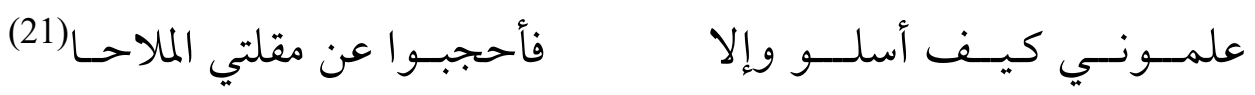

أوزان الموشتحات:

يكتسب فن الموشّحات جماله وتميزه، من حرية الوزن، وهي - مع هذا - حرية تقودها أذن موسيقية

وضرورات الثلحين (22).

تنقسم إلى قسمين:

1 - ما جاء على أوزان أشعار العرب، وهو قسمان: 
الأول: ما لا يأتي بين أقفاله وأبياته كلمة تخرج تلك الفقرة عن الوزن الشعري، وإن جاء فالموشّح مرذول، ويكون أشبه بالمخمسات، ولا يفعله إلا الضعفاء في الشعر، ولكن إذا كان قوافي الأقفال مختلفة فهذا يخرج الموشّح عن مشابهة المخمسات، ومثاله قول ابن زهر في موشحه وهو على بحر المديد:

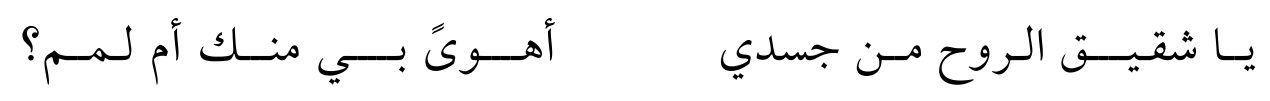

ضعت بين العذل والعذَلِ

أنـا وحسـدي علــى خبلٍ

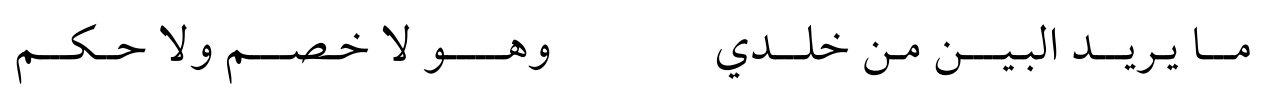

أيها الظبي الذي شردا

ترَكَتنــي مقلتاكَ سدًا

زعمــوا أني ار الك غدًا

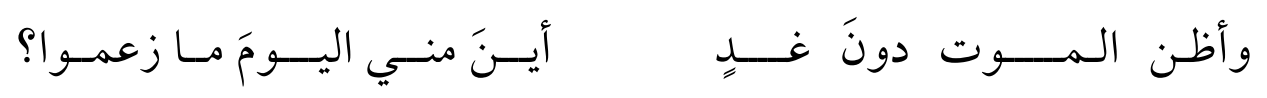

فقد جاءت التفعيلات على بحر المديد التي تعرضت للزحافات و العلل

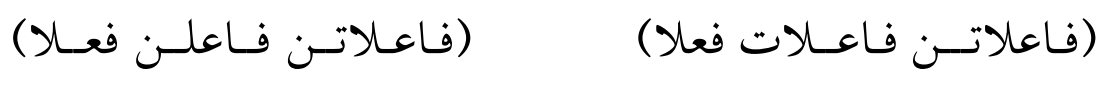

وجاءت قوافي الأغصان خختلفة(23).

الثاني: ما تخللت أقفاله وأبياته كلمة أو حركة ملتزمة، ومثاله قول ابن بقي:

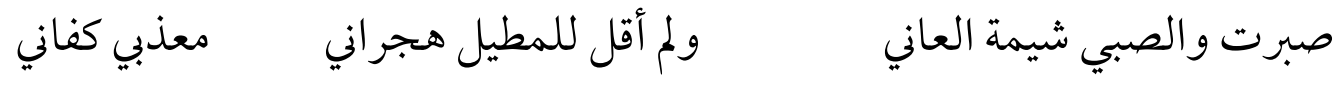

فجاء البيت على بحر المنسرح (مستفعلن مفعولات مفتعل)، وقد أخرجه ابن بقي عن بحر المنسر بقوله: (24)(معذبي كفاني)

2- ما لا مدخل لشيء منه في شيء من أوزان العرب، وهو أكثر الموشّحات، فسائر الخرجات العامية في الموشحات العربية والعبرية ضمن العروض العربي او المولدة منه وليس للعروض الاسباني نصيب ولا مدخل 
لشيء منه، وقد حاول المستشرق الألماني "هارتمان" إرجاع أوزان الموشّحات إلى 146 وزنًا أو بحرًا مشتقة من بحور الشعر العربي الستة عشرة، ولكن في هذه المحاولة تكلف وتصنع؛ إذ هناك موشحات تشذ عن الأوزان التي ذكرها هارتمان في كتابه، ولا تخضع لها(25)، قال ابن سناء الملك: (وكنت أردت أن أقيم لها عروضًا يكون دفترًا لحسابها، وميزانًا لأوتادها وأسبابها، فعزَّ ذلك وأعوز، لخروجها عن الحصر، وانفلاتها عن الكف)|(26). ومن أمثلة الموشّحات التي تبين خروج الموشّح على النظام الخليلي قول عبادة بن ماء السماء في مطلع موشحته:

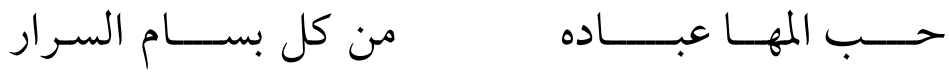

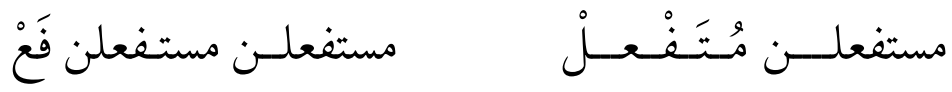

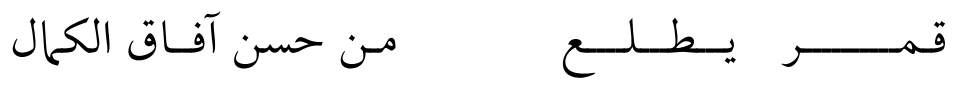

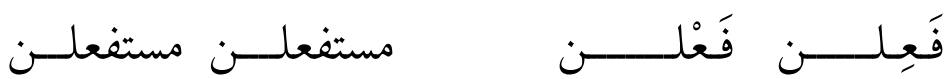
فـاعلــــن فــاعلـــن

وقد خرجت الموشّحة في البيت الثاني عن الرجز إلى المتدارك (27). وقول محمد بن عبد الملك بن زُهر:

يـا لـــهـ سكـــــان من شكره لا يفيـتق

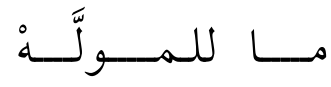
ينـدبُ الأوطــــان؟

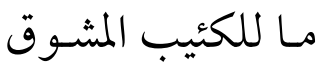
من غيــــر خـمــر

وقد تداخلت في هذه الموشّحة تداخلت نغحات تفعيلات مستفعلن مع فاعلاتن، مع زيادة بعض المتحركات أو السو اكن في أطر اف كل تفعيلة(28). وبعض الموشّحات نظمت على وزن مهمل (29)، مثل قوله:

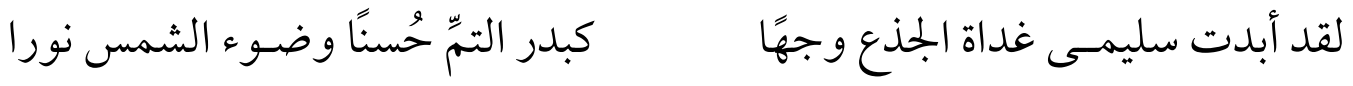
فجاء البيت على بحر المستطيل أو الوسيط (مفاعيلن فعولن)، وهو بحر مهمل جاء من مقلوب بحر الطويل (فعولن مفاعيلن) (30) 
وثَمَّم تقسيم آخر للدكتور مقداد رحيم؛ يُخْجرج إلى أن الموشّحات لها قو اعد ونظام تسير عليه، وإن خالفت في بعض أنواعها نظام القصيدة القديمة؛ فقد قسمها إلى أربعة أقسام، وهي: 1 - ما جاء على أوزان الشعر العربي صافيًا، وهذا له شكلان:

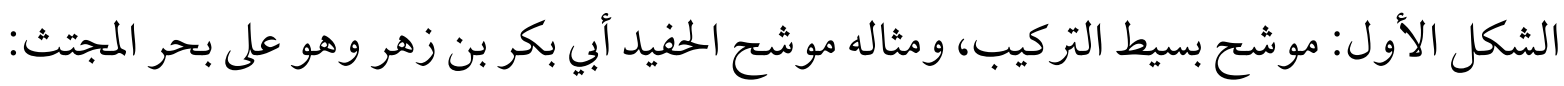

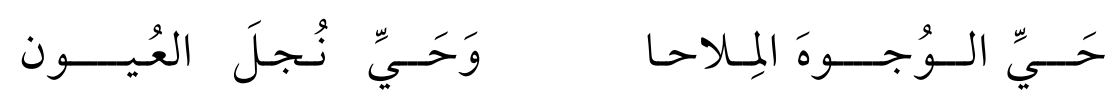

الشكل الثاني: موشح معقد التركيب، ومثاله موشح إبراهيم بن سهل الأشبيلي، وقد جاء على مجزوء الرجز:

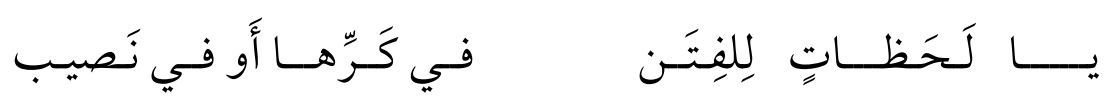

2- ما جاء بعضه على أوزان الشعر العربي وبعضه الآخر من الأوزان الجديدة المبتدعة في الأقفال والأدوار

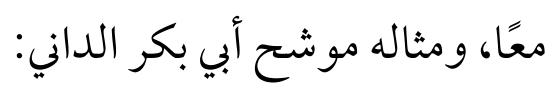

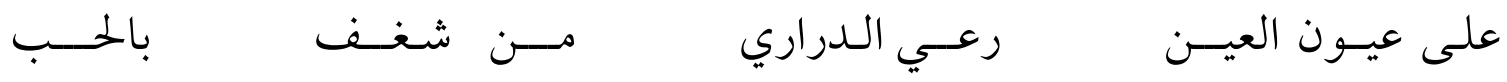

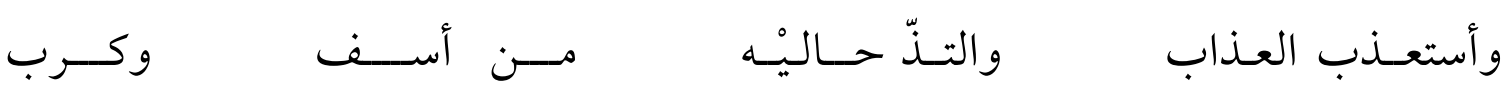

3- ما جاءت أدواره على أوزان الشعر العربي المعروفة، وأقفاله منها ومن غيرها، وهو الكثير الشائع، ومثاله

$$
\text { موشح المرسي الخباز: }
$$




$$
\begin{aligned}
& \text { حملت من كل حسن ليس تدرك بالوصف }
\end{aligned}
$$

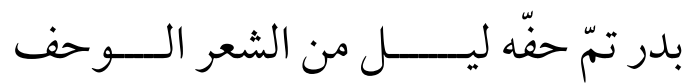

$$
\begin{aligned}
& \text { تحته وجـه من السوسان بالمسك مرشوش أن الحســن تنميـق وبشـر وترقيــــش }
\end{aligned}
$$

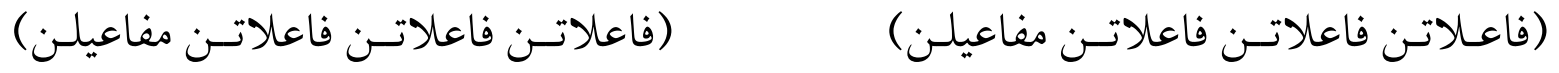

$$
\begin{aligned}
& \text { عاهدت بل حلفت ألاّ تقيـــم على العهد } \\
& \text { فشكت ذاك وقـــالت سألتـــــك بالــــود } \\
& \text { فارتشفت الشهد من فيها وملت إلى النهد } \\
& \text { ثم عــادت عطفت حنّت فزارت بلا وعد } \\
& \text { (فـاعلاتن فـاعلاتن فـاعلاتن مفاعيـلن) ( }
\end{aligned}
$$

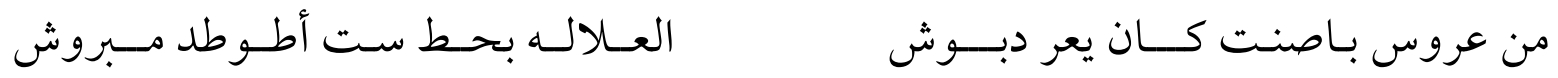

ب. ما كانت أدواره على وزن و احد، و أقفاله على وزنين، ومثاله موشح أبي بكر بن زهر:

$$
\begin{aligned}
& \text { يا صاحبي نداء مغتبط بصـــاحبْ }
\end{aligned}
$$

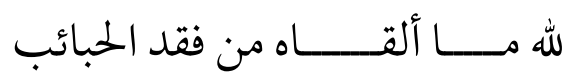

$$
\begin{aligned}
& \text { قلب أحاط به الجوى من كل جانب } \\
& \text { لا يستريسح إلى اللواحي لي } \\
& \text { أي قلــــب هــــــــائـمـ }
\end{aligned}
$$

ت. ما كانت أدواره على وزن واحد، وأقفاله على أكثر من وزنين، ومثاله موشح أبي بكر أحمد بن مالك

$$
\text { مــن ذا يـهـيــــم م السرقسي: }
$$




\begin{tabular}{|c|c|c|c|}
\hline نـواهـد كالتـفــا. & والأرمـاح & تردي على الحين & هـــــا كلــــــــومْ \\
\hline شذا العنبر النفّــا & كمـا فـاح & كمسـك داريــــن & هــــا شـمــــــــم \\
\hline ف) & (فعـولن) & (مستف & 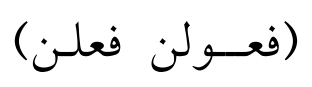 \\
\hline
\end{tabular}

$$
\text { فقتنـي وو اليت سقيــاها }
$$

ترد الظلام صباح

$$
\text { أشـرب وغنيـني }
$$

$[\ldots \ldots]$

ث. ما كانت أدواره على وزنين وأقفاله على وزنين، ومثاله موشح أبي عامر بن ينق:

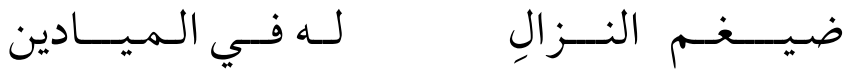

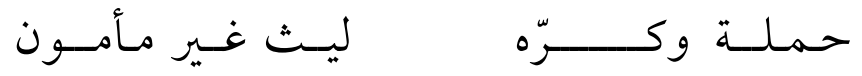

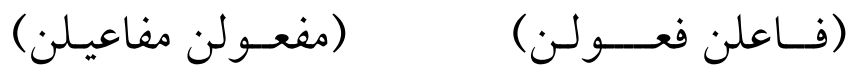

$$
\begin{aligned}
& \text { كم سطـا وصــــالا في الحرب على الأسد }
\end{aligned}
$$

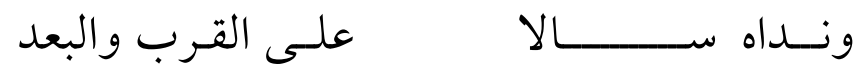

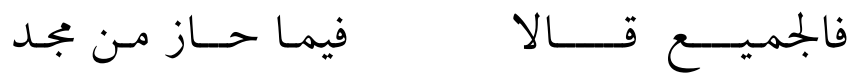

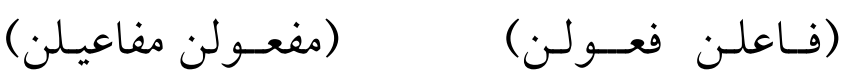

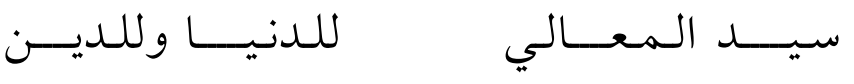

$$
\begin{aligned}
& \text { كـــاشف المـضرَّه }
\end{aligned}
$$

ج. ما كانت أدواره على وزنين، وأقفاله متعددة الأوزان، ومثاله موشح أبي بكر بن بقي:

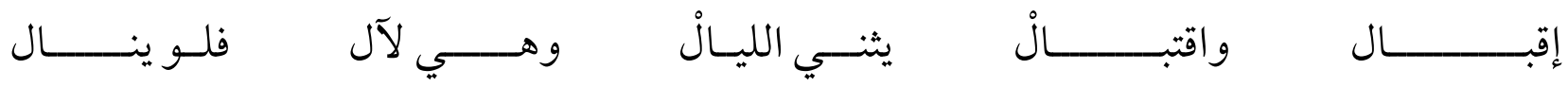

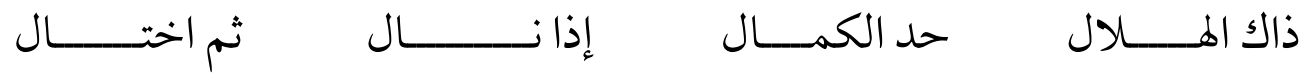




$$
\begin{aligned}
& \text { يـا من علي قد أثنى } \\
& \text { تبريــز مجــــــك } \\
& \text { أن أقيموا فنحن منـا }
\end{aligned}
$$

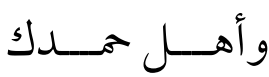

$$
\begin{aligned}
& \text { نال الجميع ما تمنسى } \\
& \text { في يمسن سعـــك }
\end{aligned}
$$

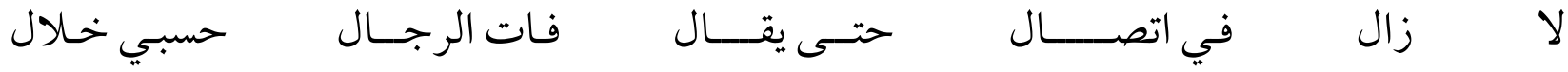

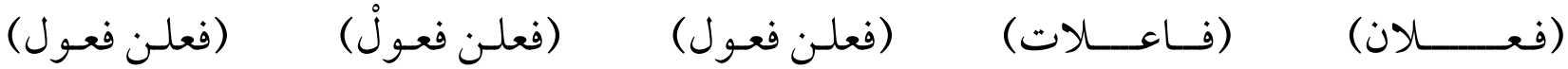

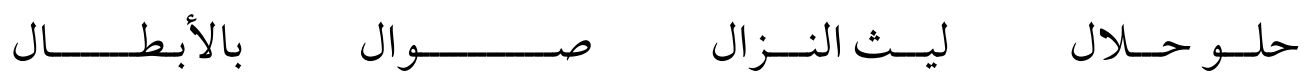

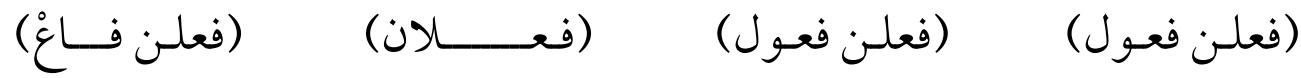

$$
\begin{aligned}
& \text { لم لمره إلا العقــول } \\
& \text { إلا ويبديه النحــول } \\
& \text { لا يستســــر } \\
& \text { عواذلي بها أقــــــول } \\
& \text { تسرى تســـر }
\end{aligned}
$$

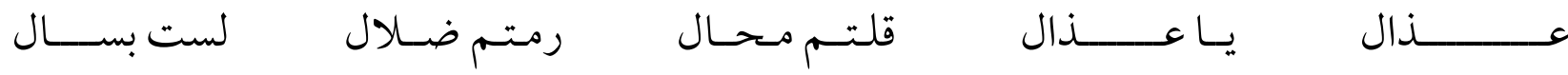

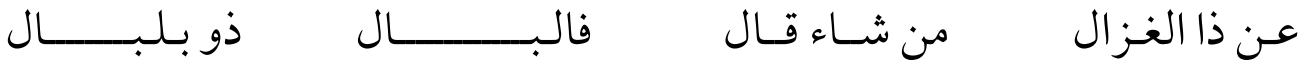

$$
\begin{aligned}
& \text { ح. ما كانت أدواره على ثلاثة أوزان، وأقفاله على ثلاثة أوزان، ومثاله أبي بكر الصيرفي: }
\end{aligned}
$$

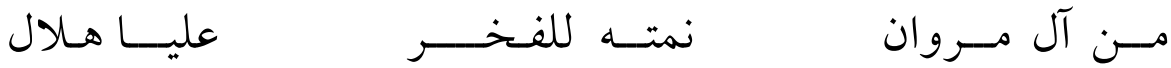

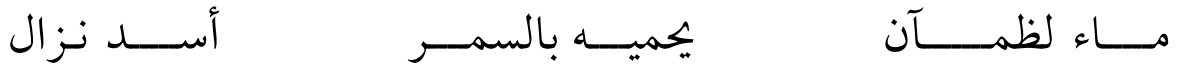

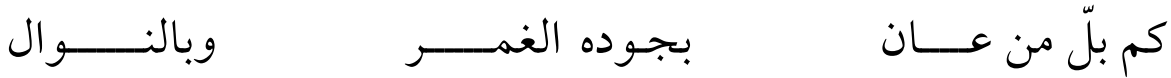

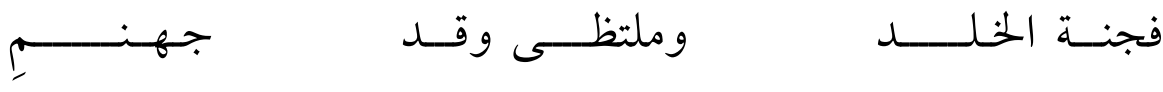

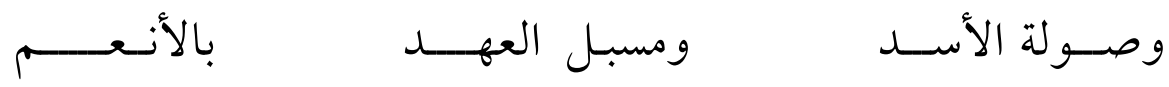

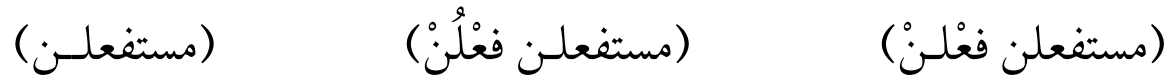

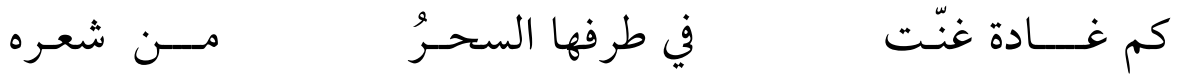

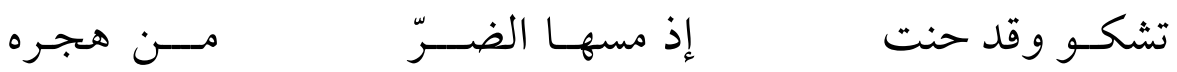




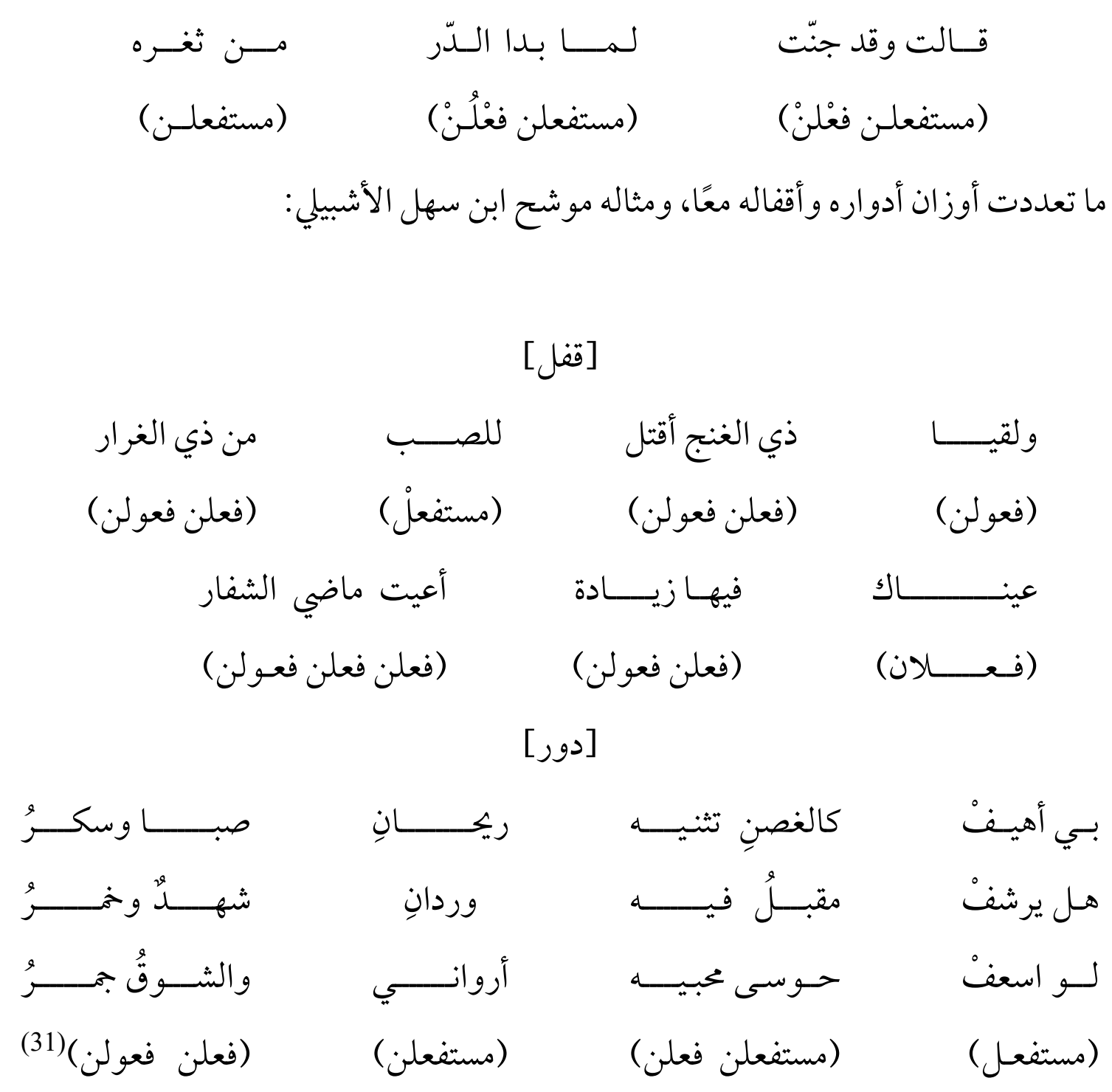

\section{قافيـة الموشّح:}

يعتمد نظام التقفية في الموشّحات على المراوحة بين قوافي كل من الأدوار والأقفال، فالقافية الثابتة تكون في الأقفال وتغيير في الأدوار من دور لآخر (32).

\section{تطور الموشّح:}

مر الموشّح خلال مسيرة طويل من التطور حتى يصل إلى شكله النهائي، ومن أبرز مراحل تطوره: 
1 - بدأ أول ظهور للموشح على شكل منظومو غنائية، من صنع زرياب، يخضعها لألحانه المبتكرة المتميزة، وكان ينظم على أسطار الأشعار المهملة وقد لا يتقيد بوزن ولا قافية. 2- أدخل محمد بن محمود القبري تطورًا آخر على الموشّح، فقد كان يأخذ اللفظ العامي ويضع عليه الموشّحة دون تضمين فيه ولا أغضان. 3 - أول من أكثر في الموشّحة التضمين في المراكيز (الأقفال)، ثم أحدث عبادة بن عبد الله الأنصاري الملقب بابن ماء السماء التضفير، وعلى يده اكتملت صورة الموشّحة، وتفرت لها جميع عناصرها الفنية(33).

\section{خصائص الموشّحات: 1 - الجمع بين الفصحى والعامية.}

2-تحرير الوزن والقافية وتوشيح أي ترصيع أبياتها بفنون صناعة النظم المختلفة من تقابل وتناظر واستعر اض أوزان وقو افي جديدة تكسر ملل القصائد

3 - أن تلحينها جاء مغايرًا لتلحين القصيدة، فاللحن ينطوي على تغيرات الهدف منها الإكثار من التشكيل و التلوين، ويمكن تلحين الموشّح على أي وزن موسيقي، لكن عُرفت لها موازين خاصة غير معتادة في القصائد وأشكال الغناء الأخرى (34). وترى الباحثة أنه من خلال ما سبق من ذكر أنواع أوزان الموشّحات، وما جاء في نظام التقفية؛ أن فن الموشّحات إن كان فيه خروجًا على نظام القصيدة القديمة؛ فليس هو تحرر من النظام، وإنها هو يخضع لقو اعد وقوانين تتناسب مع طبيعة الغناء و التلحين التي امتازت بها بلاد الأندلس. فالموشّح الواحد يعتمد على أكثر من وزن وأكثر من قافية، فها فيه من التنويع العروضي أقرب إلى التنويع الموسيقي؛ بحيث تجد الموشّحة أقرب إلى القطعة الموسيقية منها إلى القصيدة الشعرية(35)، وهذه التنوع نابع من حب الأندلسيين للزخرفة والتنمق، وولعهم بكل جديد؛ مما انعكس على أشعارهم، فاخترعوا هذا الفن الشعري الجديد، فاخترعوا أوزانًا تساعدهم على ما يريدون من الكلام في بحبوحة اللهو و الطرب والرقص، و إنشاد الشعر بطريقة خفيفة على النفس (36). 


\section{المطلب الثالث: آراء المحدثين حول الموشّحات}

اختلفت آراء الباحثين حول أصل نشأة الموشّحات؛ هل هو آلموشحات أندلسي، أم مشرقي، أم أعجمي؛ على النحو التالي:

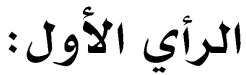

يرى بعضهم أن نشأة فن الموشّحات بدأت في الأندلس بشكل بسيط على يد محمد بن محمود القبري الضرير ثم نضجت وازدهرت على يد عبادة بن ماء السماء وعرف به كثير من الوشاحين ثم انتقل إلى المشرق في الحقب المتأخرة واصبح له اسس ومبادئ علمية بفضل ابن سناء الملك فنسج المشارقة على منو اله(37)، وهذا هو الشائع المشهور (38)، وقال ذكر ابن خلدون أول من نظم الشعر على نظام الموشّحات من شعر اء الأندلس فقال: (و كان المخترع لها بجزيرة الأندلس مقدّم بن معافر الفريريّ، من شعراء الأمير عبد الله بن محمّد المروانِيّ. وأخذ ذلك عنه أبو عبد الله أحمد بن عبد ربّه صاحب كتاب العقد، ولم يظهر لهما مع المتأخّرين ذكر وكسدت موشَّحاتهها، فكان أوّل من برع في هذا الشّأن عبادة القزّاز شاعر المعتصم ابن صمادح صاحب المرية)|)(39، فكانت لعبادة القزاز دورًا في تجديد شعر الموشّحات؛ قال ابن بسام: (اوكانت صنعة التوشيح التي نهج أهل الأندلس بـ طريقتها، ووضعوا حقيقتها، غير مرقومة البرود، ولا منظومة العقود، فأقام عبادة هذا منآدها، وقوم ميلها وسنادها، فكأنها لم تسمع بالأندلس إلا منه، ولا أخذت إلا عنه، واشتهر بها اشتهاراً غلب على ذاته، وذهب بكثير من حسناته(140).

\section{أرأي الثاني:}

وهو رأي جماعة من الباحثين العرب - مثل يوسف أسعد، وبطرس البستاني، وحنا الفاخوري وغيرهم والمستشرقين - مثل : مينيندز بيلينو، وريبيرا، وجب، وبروكلمان، وغيرهم - ذهبو ا إلى أن فن الموشّحات غربي الأصل، وإنما انتقل إلى الأدب العربي من خلال الأغاني الشعبية الإسبانية (الفلامنكو )، والبروفنسانية اللاتينية التي كانت تعرف بالرومانسية من خلال جماعة الرواة والمغنين المعروفين في فرنسا بالتروبادور وجنكلر من العصر الوسيط (القرن السابع والثامن الميلادي) الذين كانوا يطوفون البلاد ويقصدون الأمراء في المواسم والأعياد، يتغنون بأناشيدهم الغرامية وقصص الفروسية في مقاطع غير ححكمة الوزن، ولا تلتزم فيها القوافي، 
وقد عرض المستشرق إميليو غارسيا غو مث في كتابه "الموشّحات الأندلسية والعروض الإسباني" لسبعة ألو ان من إيقاعات الشعر وموسيقاه أراد بها ضم الموشّحات التي يضمها جيش الترشيح للسان الدين ابن الخطيب

$$
\text { إلى العروض الإسباني (41). واستندوا في ذلك على ما يلي: }
$$

2 - تشابه الموشّحات مع هذه القصائد في كونها غير محكمة الوزن ومختلفة القافية.

3- وجود جو انب مشتركة بين الموشّحات و المنظومات التروبادورية حيث نجد في مقطوعة من المقطوعات

التروبادورية جزء يقابل الغصن في الموشّحة وجزء يقابل القفل، ومن نقاط الالتقاء أيضًا أن ما يقابل

الغصن مع ما يقابل القفل يسمى عند جماعة التروبادور بيتًا كما هو الحال عند جماعة الموشّحات(42). وناقش المستشرق فيدريكو في مقال له عن دعوى بعض المستشرقين أن عروض الموشّح من أصل أسباني، و انتصر لأصلها العربي؛ فقال: (إن العلم)ء العرب مع طول اطلاعهم على التوشيح والزجل الذين سموهما الفنين عادة واختصارًا؛ لم يروا فيها غير استنباط أندلسي طريف، كانوا يعدونه من مفاخر أهل الأندلس، أما العلماء الغربيون فإنهم لمّا تعرفوا على وجود الفنين في أواخر القرن الماضي، واطلعوا على عدد من نماذجها في المخطوطات المشرقية قبل المغربية، وكان رائدهم في ذلك الأستاذ الألماني هارتحان، فسرعان ما لاحظوا الفوارق البنيوية بينها وبين الشعر العربي المقصد، فتبادر إلى عقول بعضهم أنها عسى أن ترجع إلى أن أصلها أندلسي وليس هذا بعيدًا كل البعد، وظن بعضهم أن مصدر ذلك الاستباط الغريب إنما هو بقاء تراث عربي أسباني قديم ذي شأن عظيم في بلاد الأندلس؛ بحيث أن العوام من الملل الثلاث المسلمين والنصارى واليهود ظلوا يؤلفون ويغنون أغانيهم الرسمية والشعبية بأعاريضها الأصلية وأغانيهم الخاصة بهم، ثم أتى بعض الشعراء الأندلسيين المعجبين بها، فنسجو اعلى منو الها الموشّحات في مرحلة أولى بلغة عربية فصيحة، ما عدا خرجاتها العامية أو الأعجمية، ثم تجاوزوا ذلك المقدار من الجرأة في التحرر من قيود التقاليد في مرحلة ثانية، على أن الأستاذ غارسيا غوميز كان قد شط في هذا شططًا لم يكن من اليسير التغاضي عنه عندما اقترح تقطيع الموشّحات بأعاريض غير عربية، ودخل الأستاذ فيدير كوكورنتي في تفصيل طويل لهذه الأقو ال غير أنه خلص 
إلى الآتي: قال فيتبين من هذا القول أن الزجل القديم كان عبارة عن دوبيت يقوله الشعب بالعامية أو

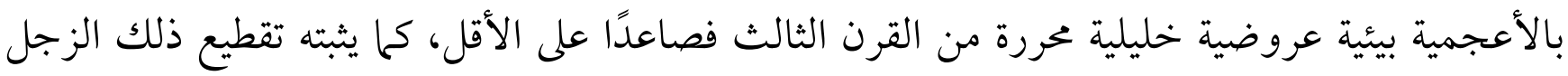

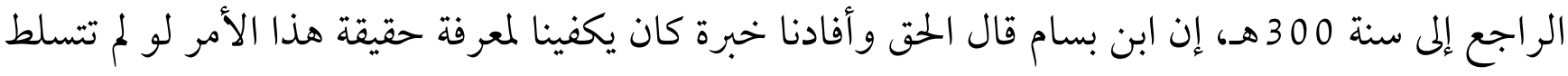
علينا الهو اجس عندما قال عن مخترع التوشيح محمد بن محمود بن القبري الضرير أنه كان يصنعها على أشطار

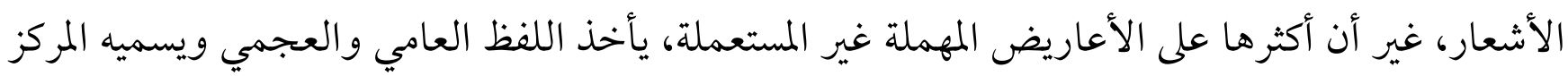

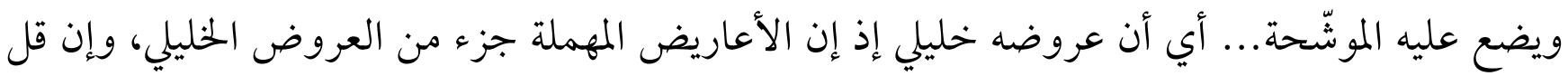

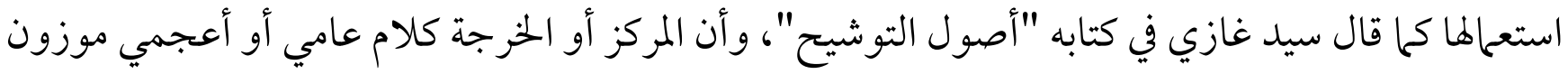
بالعروض الخليبي" (43). وقد عكس بعضهم - مثل ليفي بروفنسال وبنكل وكراتشوفسكي، ومقداد رحيم وبجدي شمس الدين

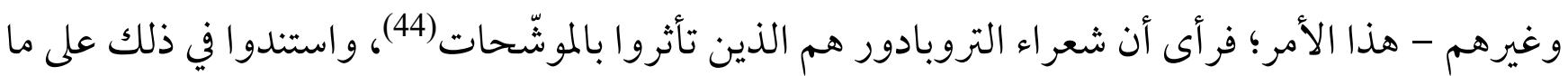
يأتي: 1 - إن أول شاعر تروبادوري هو جيوم التاسع أمير بانييه الذي كتب أشعاره بين سنة 1100 -1127م؟ أي بعد أقدم الموشّحات بأكثر من 200 سنة. 2- التقارب بين الموشّحات واغاني التروبادور كتقابل الأغصان والأقفال. 3- أن ظاهرة الموشّحات غريبة على الشعر الأوربي قبل جماعة التروبادور (45).

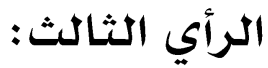

يرى بعضهم - مثل د. عبد العزيز الأهواني - أن الموشّحات أعجمية الأصل، دون تحديد أصل نشأتها، ويستند هذا الر أي على الخرجات الأعجمية التي احتوت عليها الموشّحات (46). يقول الأستاذ فيديريكوكوريتي كوروفا عن إشكالة الخرجات المسماة بالأعجمية في الموشّحات: "... فتحولت

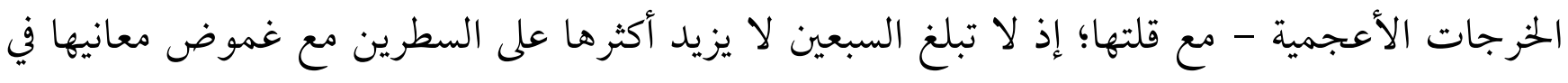

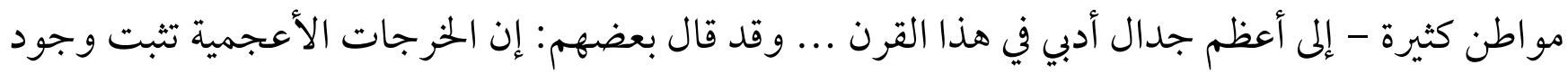


تراث شعري وافر باللغة الإسبانية القديمة، وبعروض أهلي كامل الذات، وموضوعات مطروقة لدى الأندلسيين المولدين وإخوانهم من أهل الذمة ... وسمى بعضهم هذه الأشعار بشعر مستعرب إلماحًا منهم بذلك إلى أن أصحابه ليسوا غير المستعربين؛ أي النصارى الذميين دون الأندلسيين المسلمين ... و إنها صدرت تلك الأقوال عن أوهام وأضغاث أحلام" وكان من نتاج هذا أن فتر غارسيا غرمين بعض الخرجات بعد أن أجرى تعدية فيها ليحمل تفسيرها على أنها من اللغة الأسبانية واتهمه الكاتب بتحريف النص ليو افت غرضه وضرب مثلاً لهذا قال: "وفي هذا الباب نفسه كثر النقاش حول موضع شكوى الفتيات إلى أمهاتهن ألام غرامهن في الخرجات، وذكراين استعالهن لكلمة "ما" الأعجمية عوضا عن" يا أمت العربية من أقوى الأدلة على أنهن أمهات نصرانيات شماليات حديثات عهد بالأسر والإقامة في الأندلس، إذن فهي نظرية غريبة إذ ليس معقو لا أن يشتري الإنسان الجارية مع أمها ولم تلبث أن تعرضنا لهذه الأبحاث حتى عثرنا على ما يدحض

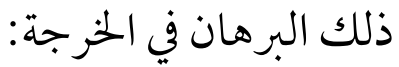

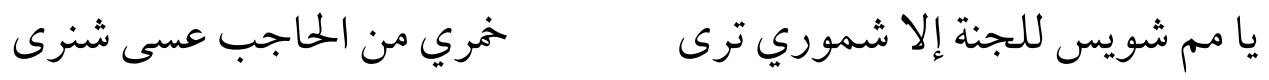

وقد فسرها كل من غارسيا غوميس وسولا سوليه بفوارق تافهة، على أن معناها "يا أمي إن لم يزل جنون عشقي أمت، فأحضري خري من الحاجب أو جعفر لكي أشفى منه"، ولم يتبه أحدهما إنما هي سورة (يس) القرآنية التي يقرؤها المسلمون مستغيثين بالله على البلايا ، فإن معنى هذه الخرجة الصحيح" ما الفائدة من تلاوة سورة يس في حال الجنون، بل أحضري لي الحاجب أو جعفر خرًا أو دواء... ومضمونها أن العاشقة اليائسة في المرشحة ترفض طلب أمها في طلب الفرج عن همومها بالصلاة، وتطلب منها إحضار معشوقها علاجًا لما بها من ذلك، وهذه القصة مع ما فيها من الكفر بالدين بسبب اليأس وجسارة البنت على أمها ما كانت لتحدث في غير بيئة عريقة الإسلام ومع أن الأستاذ فيديريكو يدافع عن المسلمين وحقهم الأدبي، إلا أن رميه البنت بالكفر خطأ كبير، وليس هذا نهج الإسلام في التكفير، وإنها تذكر منها أنه ليس بها مم من الجن وإنما هو داء العشق وليس لها دواء، إلا الاجتتاع بالمعشوق، ومن الواضح أن ناظم الخرجة نظر إلى قول عروة بن حزام عندما اتهموه بالجنون وأر ادوا أن يذهبوا به إلى من برقيه: 


$$
\text { فما بي من سقم ولا طيف جنة ولكن عمي الحميري كذوب }
$$

بل يعد هذا دلياً إضافيًّا على أن الناظم عربي مسلم متشرب بالثقافة الإسلامية العربية. أما دخول الألفاظ الأعجمية فكثير في الشعر العربي منذ الجاهلية يقول الأعشى يصف بجلسًا لكسرى:

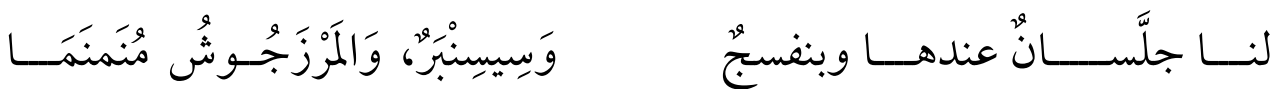

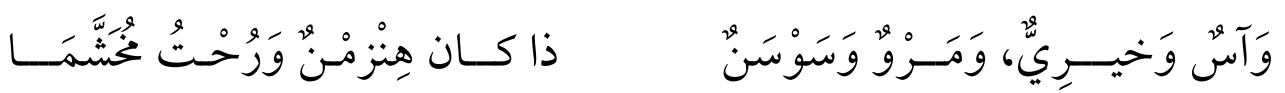

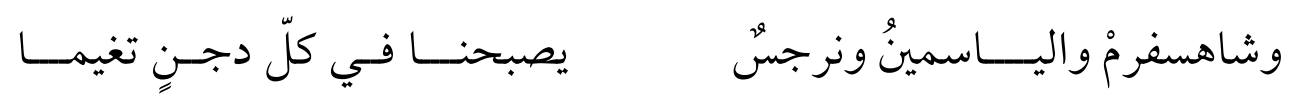
والأمثلة لهذا كثيرة في الشعر العربي، خاصة في العصر العباسي، وهو نتاج طبيعي لتلاقح الثقافات واللغات المختلفة"(47).

كما بين الأستاذ هلال ناجي في مقدمة كتاب "جيش التوشيح)" ضعف هذا القول بها خلاصته: 1 - أن ادعاء وجود شعر غنائي قد سبق الموشّحات عند الرومان أو غيرهم إنما هو افتراض لا دليل عليه، ولا يو جد نموذج لهذا السابق الذي ادعوه. 2- أن الخرجات وإن كانت أعجمية، فهي موزونة وزنًا عربيَّ، وهي من تأليف الموشّحين أنفسهم، وقد أضافو ا إليها في مواضع كثيرة كلمات عربية. 3 - أن المستشرق (غرسيه) قد استند في دعم نظريته على تفسير كلام ابن بسام في كتابه الذخيرة، وابن بسام لم يصرح بأن الشاعر كان يأخذ الخرجة من الشعر الغنائي الروماني (48). فالخرجات الأعجمية، ناتجة عن تمازح الحضارات والتقائها، كما كانت وسيلة لإرضاء الذوق العام الذي لم يكن يستسيغ الشعر الفصيح وتلحينه ليصبح أغنية جاهزة للاستحاع. ولذلك لبت الخرجات الأعجمية حاجة المغنيين وو افقتها تلك الأوزان والقوافي، التي اتخذت إطارًا غير تقليدي(49). 


\section{الرأي الرابع:}

يرى فريق من الباحثين - مثل د صفاء خلوصي، وكامل الكيلاني -، أن الموشّحات مشرقية الأصل ولد على يد ابن معتز ثم انتقلت إلى الأندلس، وهذا القول ضعيف فإن تلك الموشّحات المنسوبة إلى ابن المعتز منحولة عليه، وإنما هي أندلسية التأليف(50).

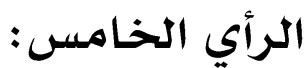

يرى أن الموشّحات إنما هي تطور طبيعي لنظام الشعر العربي، ويستند هذا الرأي إلى ما ورد عند عدد من الشعراء من محاولات للخروج على الأوزان والقوافي، كمحاولة للتجديد في الشعر العربي، ويعتبرٌ هذا الرأي الموشّحات من هذا النمط، خاصة وعصر الموشّحات كان بحاجة لهذا التجديد للحاجة الملحة إلى غناء الشعر العربي، والموشّح يؤدي هذا الغرض، فهو ثمرة من ثمرات هذا التجديد(51). فالذي يظهر من أغلب الموشّحات أن "الموشّح عربي في أسلوبه و ألفاظه وتر اكيبه، وقد تكون به بعض الألفاظ غير العربية، وكلما تقدم الزمن به زادت قلة العناية بالإعراب فيه، وإن كان لا يخرج في جملته عن الأسلوب العربي، وذلك عدا الخرجة، وهي آخر قفل من المرشح، وهي غالبًا ما تكون فكاهة ... جارية على لسان ناطق أو صامت"(52). (20.

وترى الباحثة أن هذا الرأي الخامس قوي جدَّا، ويتقوى بالنظر إلى ما أضافه فن الموشّحات من تجديد في استعحال الأوزان والقو افي بطريقة تخدم متطلبات العصر والبلد الذي نشأ فيه فن الموشّحات، وهذا لا يتعارض مع القول بأن الموشّحات أندلسية الأصل ثم أخذت عنهم بعد ذلك سواء في الأدب المشرقي أو الغربي؛ كما اشتهر عند القدماء، وكثير من المحدثين، ويؤكد ذلك براعة الأندلسيين فيه وكثرة استعالهم له.

\section{آراء المحدثين حول مراحل تطور الموشّحات:}

ذهب بعضهم الباحثين إلى أن الموشّحات في بدايتها كانت أقرب إلى الشعر المسمط (53)، إن لم تكن بالفعل شعرًا مسمطًا، ومن هؤلاء الباحثين الدكتور سيد غازي، وبعض المستشرقين مثل هارتمان، وفرايتاغ 
وكراتشكوفسكي؛ زعموا بأن الموشّحات الأولى لم تكن إلا مقطوعات تشبه إلى حد ما الشعر المسمط الذي

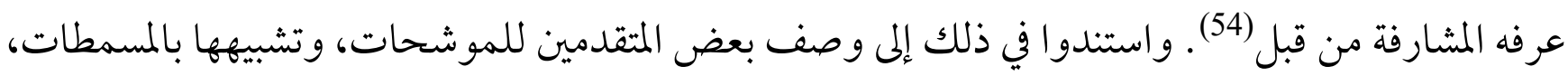
قال ابن خلدون: (اؤمّا أهل الأندلس فلمّا كثر الشّعر في قطرهم وتهذّبت مناحيه وفنونه وبلغ التّنميق فيه الغاية استحدث المتأخّرون منهم فنّا منه سمّوه بالموشّح ينظمونه أسماطا أسماطًا و أغصانا أغصانًا)، (55). يقول ابن بسام: (اوهي أوزان كثر استعال أهل الأندلس لها في العزل والنسيب، تشق على سماعها مصونات

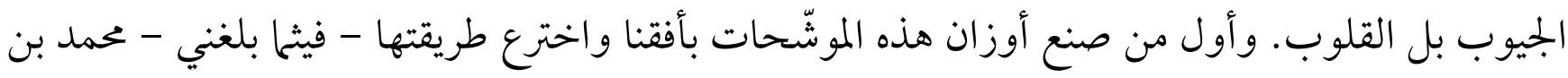
محمود القبري الضرير. وكان يصنعها على أشطار الأشعار، غير أن أكثرها على الأعاريض المهملة غير

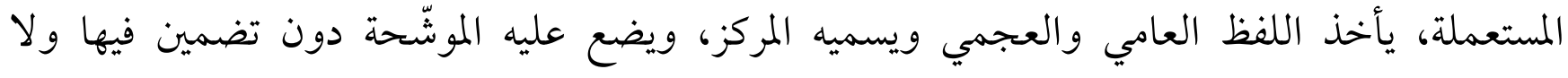

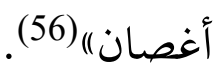

وقد ذكروا أمثلة من المسمطات قريبة الشكل من الموشّحات، قد تكون هي الأصل للموشحات، يقول الدكتور شوقي ضيف: (ايوجد لدينا شكل من أشكال المسمط نظمه ديك الجن الحمصي المتوفى سنة 235 للهجرة نظن ظنا أنه الأب الحقيقي للموشحات الأندلسية إذيرى على هذا النمط:

$$
\begin{aligned}
& \text { قــولي لطيــفك يثنــي عن مصجعي عند المنــام } \\
& \text { عند الرّقــاد عند الهجوع عند الهجـود عند الوسن }
\end{aligned}
$$

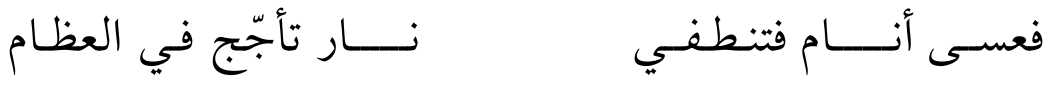

$$
\begin{aligned}
& \text { في الفؤاد في الضلـــع في الكبـــــود في البدن }
\end{aligned}
$$

ويستمر المسمط الموشّح على هذه الصورة، وواضح أنه نشأ من فكرة بسيطة هي تكرار قافية البيت برويّ جديد. وكأنما وقع هذا المسمط الغريب أو قل هذا الموشّح الفريد لمقدم بن معافى شاعر الأمير الأندلسي عبد هند الله بن محمد المرواني (275 - 300 هـ) فنظم على صورته بعض منظوماته وكتب لهذه الصورة عنده أن تشيع بعده في الأندلس باسم الموشّحات)(57). 
وعورض هذا الرأي في نشأة الموشّحات بأن بداية نشأة الموشّح سابقة على شيوع التسميط، يقول الدكتور إحسان عباس: (اومن تلك الأخطاء افتراض أن المسمطات كانت هي الأساس الذي انبثق عنه الموشّح. نعم ربها كان للأشكال المشرقية المخترعة أثر ما في المقايسة ولكن التاريخ التقديري لنشأة الموشّح سابق على شيوع التسميط، كما فهمه المشارقة؛ وإذا نحن درسنا المسمط في الأندلس وجدنا أنه واكب عصر أزهار الموشّح، و أكثر منه المحافظون الذين لم يألفوا نظم الموشّح ولا انجذبت طبائعهم الشعرية إليه من أمثال ابن زيدون وابن أبي الخصال)|(58). وترى الباحثة أن القول بتطور الموشّحات عن المسمطات ليس بعيد، فإن ضبط زمن محدد لظهور فن من الفنون أمر عسير، فدعوى تقدم فن من فنون الشعر على فن آخر من خلال تحديد عصر معين لظهور الفن أو ازدهاره غير مسلمة، لا سيا وقد ذكروا أمثلة كثيرة من الموشّحات القديمة تتو افق مع المسمطات(59. .وهذا لا يسلب من الأندلسيين أنهم من اخترعوا فن الموشّحات، فإنهم الموشّحات نظام جديد خختلف عن المسمطات.

\section{آراء المحدثين حول عروض وأوزان الموشّحات:}

أما من حيث النظر إلى تغير الموشّحات لنظام الشعر الخليلي، فيرى بعضهم أن فن الموشّحات يمثل ثورة على النظام العمودي للشعر العربي القائم على وحدة الوزن والقافية، فالموشّح أسَّس للحرية والتجديد، والغناء والتلحين (60).

بينما يرى الدكتور مقداد رحيم أن تلك الثورة لا تمثل كل الموشّحات، فقد كان من الموشّحات ما وافق تلك الأوزان وسار على نهجها، وأن هذه الثورة لم تكن من أجل التحرر من القيود التي يفرضها الشعر العمودي، و إنها نجد في الموشّحات نوعًا من القيود قد تبدو في أغلب الأحيان أشد تعقيدًا مما في القصيدة التقليدية، وإنها كانت الموشّحات نوعًا من الانطلاق إلى عالم التنويع والتعقيد والابتكار والتجديد على نطاق واسع (61). وترى الباحثة أن النظرة إلى الموشّحات على أنها ثورة على القصيدة التقليدية إنها هو من حيث النظر إلى الأغلب والأكثر في الموشّحات - كما ذكره ابن سناء الملك؛ كما مر -، وإن الموشّح في تجديد وتنويع وابتكار، وإن كان 
فيها قيودًا من نوع آخر غير موجود في القصيدة التقليدية؛ فقد استعمل الوشاحون الأوان المألوفة كما أدخلوا أوزانًا وتفعيلات جديدة، كما استعملو التفعيلات المألوفة في تراكيب جديدة مما يكسبها نغمة جديدة في الشعر

\section{النتحائج:}

الحمد لله الذي بنعمته تم الصالحات، وصلى الله على سيدنا محمد وعلى آله وصحبه، وبعد: فقد تناولت في هذا البحث أحد الفنون الشعرية المستحدثة، تعريفها وعروضها وقافيتها، وتناولت آراء المحدثين حولها، وقد وصلت من خلال ذلك إلى عدة نتائج أهمها: 1 - الموشّح فن شعري نشأ في أوساط الشعب الأندلسي خلال القرن الثالث الهجري؛ لإرضاء حاجة الشعب.

2- الموشح فن يتميز عروضيّا بتعدد القوافي، وبخروجه على بحور الشعر المعروفة في بعض الأحيان وتنويعها في الموشّح الو احد، وبتقسيمه الى أجزاء لا نجدها في ألوان النظم الاخرى مع استعهاله اللهجة العامية أو الاعجمية.

3- يعد الموشّح خروجًا على نظام القصيدة القديم المعروف عند العرب، إذ يقوم على تعدد الأوزان والقوافي، على غير المعهود في الشعر العمودي. 4 - الأساس الذي يبنى عليه الموشّح هو الأقفال والخرجة، وبدون الأقفال والخرجة لا يمكن أن تسمى المنظومة موشحًا. 5 - باستخدام الموشّحين للخرجة غير المعربة ربطو ابه بين الزجل والموشّح. 6- تنقسم الموشّحات من حيث الأوزان إلى: ما جاء على أوزان أشعار العرب، وما جاء بعضه على أوزان الشعر العربي وبعضه الآخر من الأوزان الجديدة المبتدعة في الأقفال والأدوار معًا، وما جاءت أدواره 
على أوزان الشعر العربي المعروفة، وأقفاله منها ومن غيرها، وهو الكثير الشائع، وما جاء كله على أوزان

$$
\text { غير مألوفة في الشعر العربي. }
$$

7- اختلفت آراء الباحثين حول أصل نشأة الموشّحات؛ هل هو أندلسي، أم مشرقي، أم أعجمي، وترى

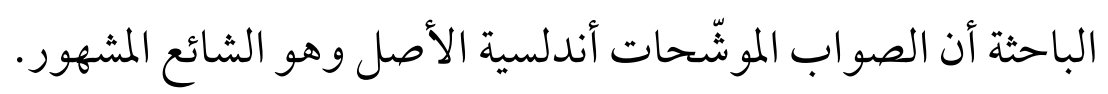

8- ترى الباحثة أن القول بتطور الموشّحات عن المسمطات ليس بعيدًا، إن ضبط زمن محدد لظهور فن من

$$
\text { الفنون أمر عسير. }
$$

9- - هذا لا يسلب من الأندلسيين أنهم من اخترعوا فن الموشّحات، فإنهم الموشّحات نظام جديد ختتلف عن

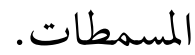

10 - ترى الباحثة أن النظرة إلى الموشّحات على أنها ثورة على القصيدة التقليدية إنها هو من حيث النظر إلى

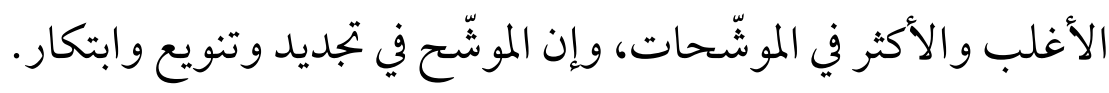

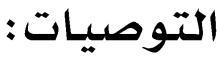

1 - توصي الباحثة بدراسة الفنون الشعرية المتطورة لمعرفة بقية الفنون المستحدثة وفنون الأدب الشعبي،

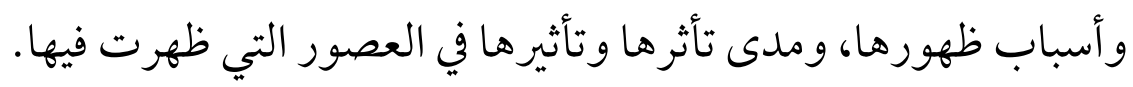
2- كما توصي الباحثة بدراسة تطور الشعر خلال عصوره المختلفة من خلال علم العروض.

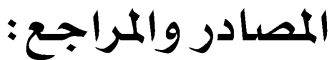

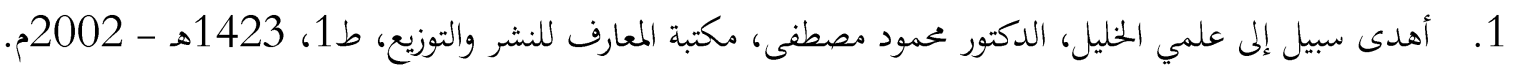

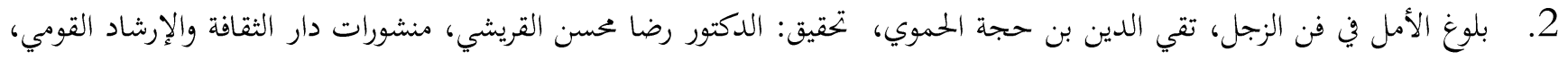

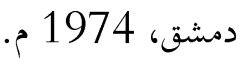
3. ت تاريخ ابن خلدون، عبد الرمن بن عمد بن عمد، ابن خلدون، تحقق: خليل شحادة.

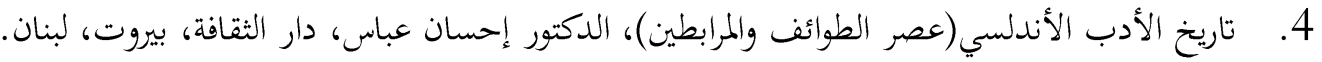

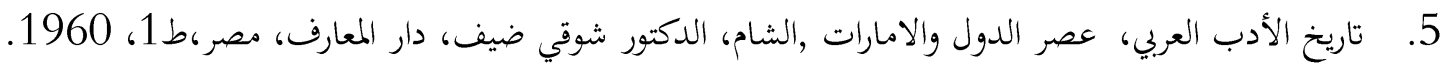


6. جيش التوشيح، لسان الدين ابن الخطيب، حققه وقدم له وترجم لوشاحيه: هلال ناجي، ومحمد ماضور، مطبعة المنار، تونس .

7 7. خزانة الأدب وغاية الأرب، ابن حجة الحموي، تحقيق عصام شعيتو، دار ومكتبة الهلال، بيروت.

8.

9. الذخيرة في محاسن أهل الجزيرة، ابو الحسن علي بن بسام الشنتريني، تحقيق الدكتور إحسان عباس، الدار العربية للكتاب، بيروت،

لبنان، 1981، 1981م.

10. عروض الموشّحات الأندلسية، دراسة وتطبيق، الدكتور مقداد رحيم، الطبعة الأولى، دار الشئون الثقافية العامة، بغداد، 1990.

11. الفن ومذاهبه في الشعر العربي، الدكتور شوقي ضيف، دار المعارف، مصر، ط12.

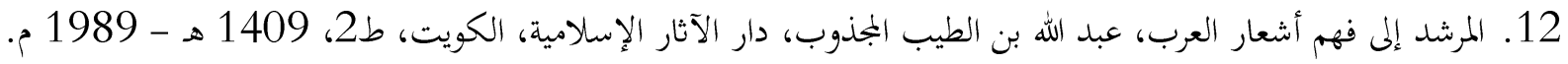

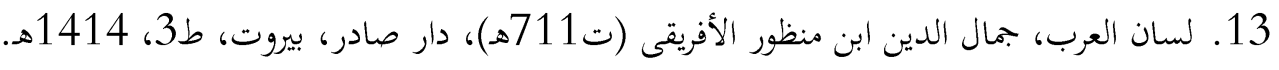

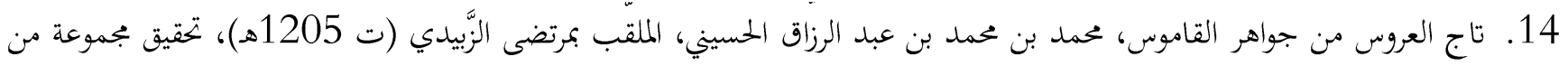

المققين، دار الهداية.

15. الموشّات الأندلسية، الدكتور انطوان محسن القوال، دار الكتاب العربي بيروت، لبنان.

16. الموشحات الأندلسية، د محمد زكريا عناني، عالم المعرفة.

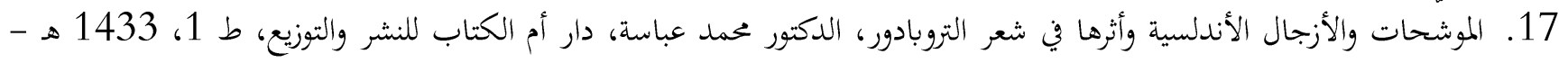

2012

18. نشأة الموشّحات الأندلسية: د. سليمان العطار ، ط1 ، 2010 م. 2010

19. عروض الموشحات الأندلسية، دراسة وتطبيق، د مقداد رحيم، الطبعة الأولى، سنة 1990، وزارة الثقافة والإعلام - دار الشئون الثقافية

$$
\text { العامة - بغداد. }
$$

20. البناء الفني للموشح النشأة والتطور، كوثر هاتف كريم، رسالة ماجستير، كلية التربية، جامعة الكوفة، 1423 هـ - 1420 21. نظرية الموشّح، ملامحها في آثار الدارسين العرب والأجانب، زهرة بوزيد، رسالة ماجستير، كلية الآداب والعلوم الإنسانية والاجتماعية،

$$
\text { جامعة أبي بكر بلقايد - الجزائر. }
$$

22. المعالم الحضارية في الموشحات الأندلسية :اللباس والزينة وعلاقتهما بالبناء الفني للموشحات، د نوال عبد الرحمن الشوابكة، د ياسمين سعد الموسى، المجلة العلمية لجامعة ابن رشد في هولندا، العدد (23)، سنو 2017.

23. البنية الموسيقية وعلاقتها بالنص الشعري، في قوالب البناء العربي الموشح أنموذجا، أنيس حمودي معيدي، العراق جامعة بابل، كلية الفنون

$$
\text { الجميلة، مجلة نابو، سنة } 2017 .
$$

24. الفنون الشعرية المطورة والمستحدثة عند شعراء الحلة في العصر الوسيط، أ.م. د محمد شاكر ناصر الربيعي، جامعة بابل/كلية التربية

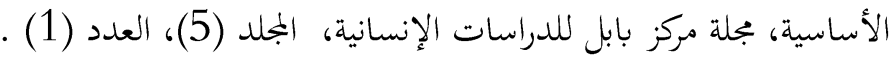

25. فن الموشحات الأندلسية (التكوين والبناء)، رونا صبري، مجلة الحوار المتمدن-العدد: (4564) بتاريخ 2014 : https://2u.pw/MfLch 
26. الموشحات الأندلسية دراسة فنية عروضية، د عبد الله محمد أحمد عبد الرمن، مجلة الجامعة الإسلامية للعلوم الإنسانية، المجلد الحادي

$$
\text { والعشرين، العدد الأول، يناير } 2013 .
$$

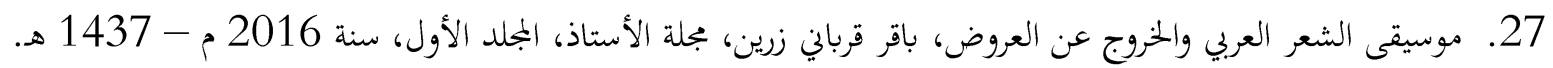

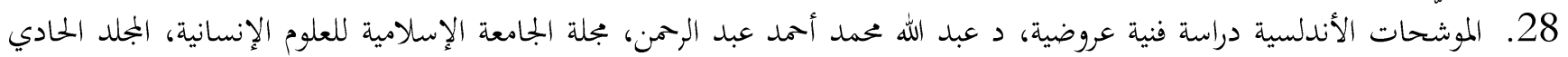

$$
\text { والعشرين، العدد الأول، يناير } 2013 .
$$

29. الموشّحات هل هي أندلسية المنشأ أم سريانية شرقية، نزار حنا الديراني، مجلة بانيبال أربيل - العراق، وانظر المقالة على موقع التنظيم http://aramean-dem.org/Arabic/Adab/Dr.Nazar/2.ht:الآرامي الديمقراطي الإلكتروني

\section{الهوامش:}

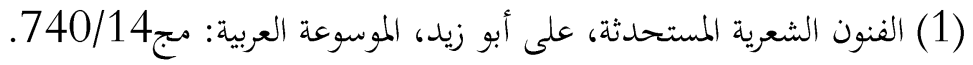

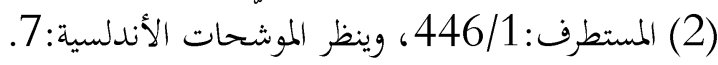

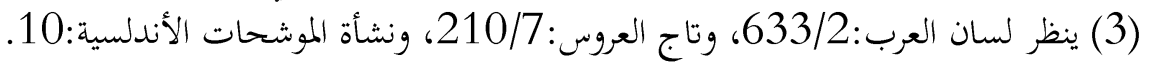

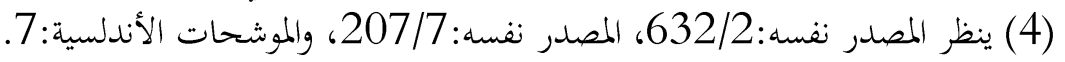

(5) ينظر المصدر نفسه: 632/2، المصدر نفسه: 208/7، ونشأة الموشحات الأندلسية:10.

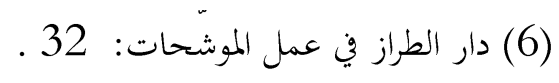

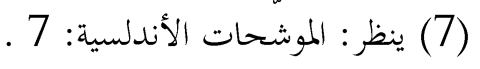

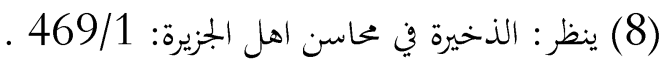

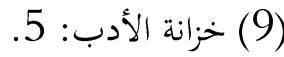

$$
\text { (10) ينظر دار الطراز في عمل الموشّحات: } 49 \text { (11) }
$$

(11) الفنون الشعرية المطورة والمستحدثة عند شعراء الحلة في العصر الوسيط (بحث): 7.

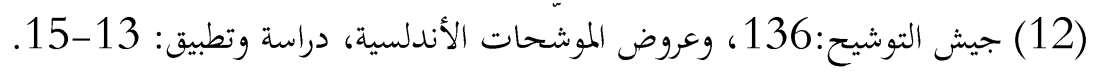

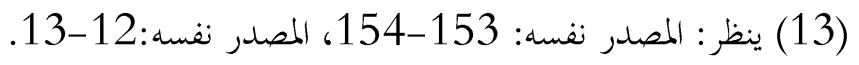

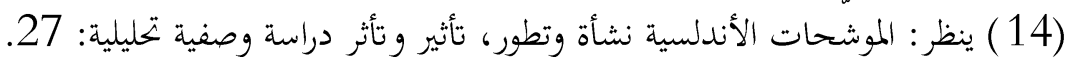

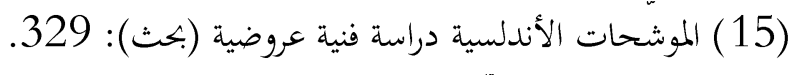$$
\text { (16) ينظر عروض الموشحات الأندلسية، دراسة وتطبيق: } 15 .
$$$$
\text { (17) ينظر المصدر نفسه: } 19 \text { (18) }
$$

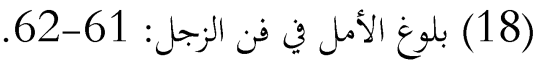

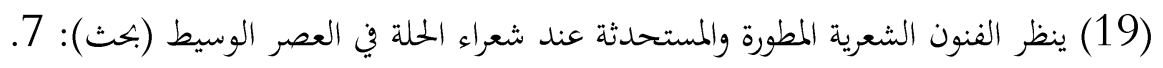

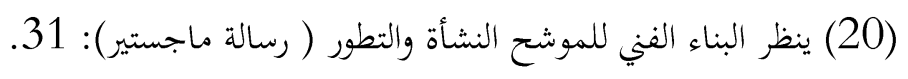

(21) ينظر دار الطراز: 45. 


$$
\text { (22) ينظر المصدر نفسه: } 13 \text { (23) }
$$

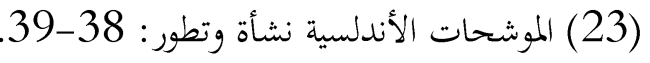

(24) المصدر نفسه: 38 (25)

(25) ينظر: دار الطراز في عمل الموشخات: 14.

(26) (المصدر نفسه: 13 (27)

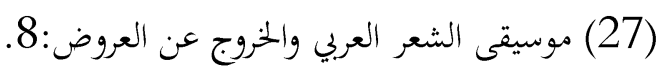

(28) المصدر نفسه: 8 (28)

(29) ينظر الموشحات الاندلسية :14 (29)

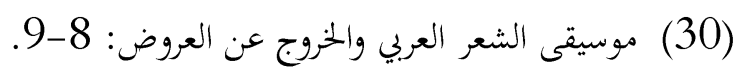

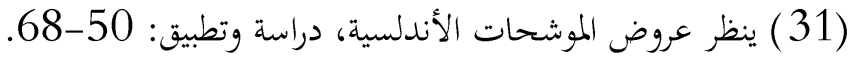

(32) ينظر عروض الموشحات الأندلسية: 11.

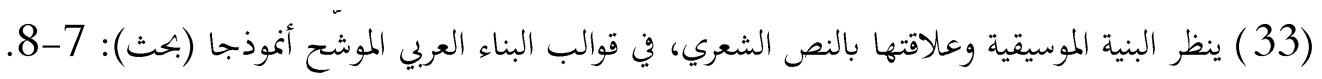

$$
\text { (34) ينظر فن الموشّحات الأندلسية (التكوين والبناء): }
$$

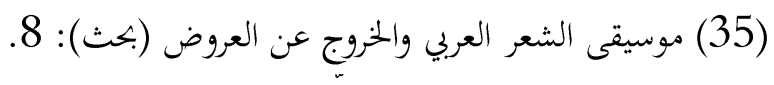

(36) ينظر المعالم الحضارية في الموشحات الأندلسية :اللباس والزينة وعلاقتهما بالبناء الفني للموشحات (بحثث): 67.

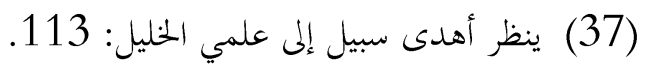

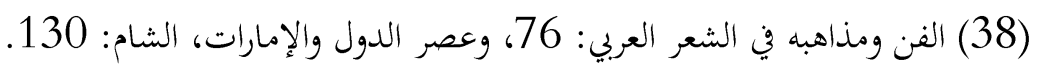

(39) تاريخ ابن خلدون: 817/1 الفن وماهبه في الشعر العري:

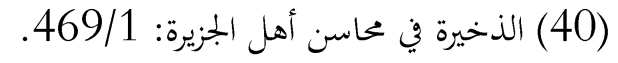

(41) الموشّحات الأندلسية دراسة فنية عروضية (بجلة): 327 المئرة

(42) ينظر الموشَحات هل هي أندلسية المنشأ أم سريانية شرقية (مقال):

(43) الموشَحات الأندلسية دراسة فنية عروضية (بحث): 327 (42)

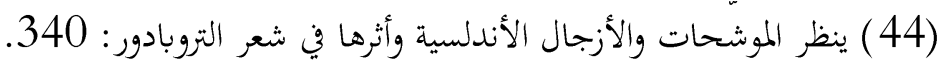

(45) ينظر الموشحات هل هي أندلسية المنشأ أم سريانية شرقية (مقال): (46) المصدر نفسه:

(47) الموشّات الأندلسية دراسة فنية عروضية (بحث): 332-333.

(48) ينظر جيش التوشيح,لسان الدين الخطيب,حققه وقدم له وترجم لوشاحيه :هلال ناجي , أعد أصلا من أصليه :محمد ماضور ,الناشر

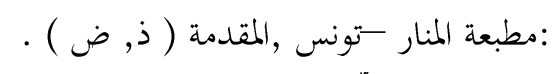

(49) ينظر نظرية الموشح، ملامحها في آثار الدارسين العرب والأجانب (رسالة ماجستير): 54 (5)

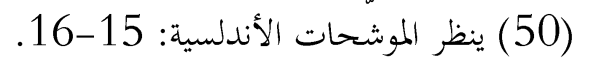




$$
\begin{aligned}
& \text { (51) ينظر الموشحات الأندلسية نشأة وتطور، تأثير و تأثر دراسة وصفية تحليلية: } 6 . \\
& \text { (52) الموشحات الأندلسية دراسة فنية عروضية: 332-333. }
\end{aligned}
$$

(53) المسمطات: نوع من الشعر ييتدئ فيه الشاعر بييت مصرع غالبا، تسمى قافيته عمود القصيدة، ثم يأتي بمجاميع من الأشطر في كل

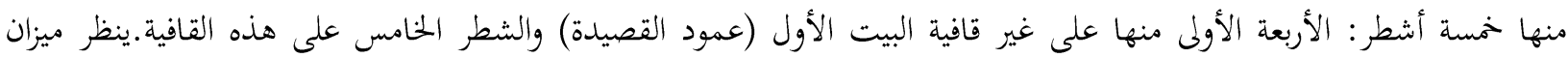

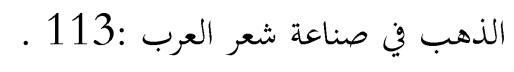$$
\text { (54) ينظر البناء الفني للموشح النشأة والتطور: 25-26. }
$$$$
\text { (55) تاريخ ابن خلدون:817/1) }
$$

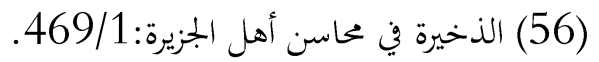

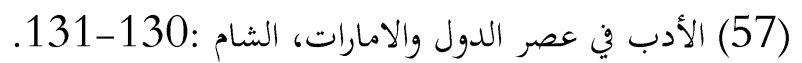

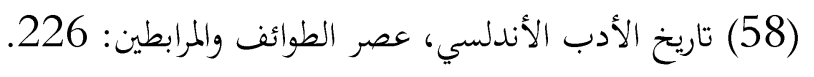$$
\text { (59) ينظر المرشد إلى فهم أشعار العرب: 25/1. }
$$$$
\text { (60) موسيقى الشعر العربي والخروج عن العروض (بحث): } 7 .
$$

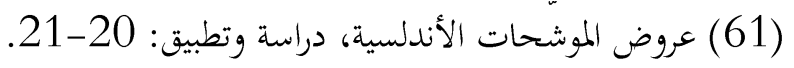

(62) ينظر الموشحات والأزجال الأندلسية وأثرها في شعر التروبادور: 79. 